\title{
Palatal Fistula Post-Cleft Palate Repair: A Tertiary Center Experience in Oman
}

\author{
Amal Al Balushi, Mohudoom Meera Sahib, Taimoor Al Balushi \\ Khoula Hospital, Muscat, Oman \\ Email: amel.albulushi@gmail.com
}

How to cite this paper: Al Balushi, A., Sahib, M.M. and Al Balushi, T. (2017) Palatal Fistula Post-Cleft Palate Repair: A Tertiary Center Experience in Oman. Modern Plastic Surgery, 7, 21-30.

https://doi.org/10.4236/mps.2017.73003

Received: April 17, 2017

Accepted: June 17, 2017

Published: June 20, 2017

Copyright (ㅇ 2017 by authors and Scientific Research Publishing Inc. This work is licensed under the Creative Commons Attribution International License (CC BY 4.0).

http://creativecommons.org/licenses/by/4.0/

(c) (i) Open Access

\begin{abstract}
One of the known complications of cleft palate surgery is development of fistula. This study highlights our experience with cleft palate surgery in relation to fistula occurrence at our center. This is one of the first studies of this kind in Oman. We retrospectively reviewed 362 records of cleft palate patients. The most common technique used for cleft palate repair at our center was VeauWardill-Kilner technique. In our series we have noticed palatal fistulae in 32\% of cases. This high rate is partially due to inclusion of very anterior fistulas in patients with complete cleft lips and palates, which actually represent part of the alveolar cleft rather than breakdown of the palatal repair. This will be closed during time of alveolar bone grafting at a later stage. We recommend a future prospective controlled study to study the factors that lower the incidence of fistula in our population.
\end{abstract}

\section{Keywords}

Palate, Palatoplasty, Palatal Fistula, Post-Operative Complication

\section{Introduction}

The management of Cleft Palate needs involvement of a multidisciplinary team which includes Plastic surgeons, otolaryngologists, orthodontists and speech language therapists. Surgical repair of cleft palate is important for feeding, normal speech mechanism and hearing. The recommended age for palate repair is between $6-12$ months [1] and repair at 18 months of age is practiced by some [2]. The surgical goals for palate repair are complete palatal closure, velopharyngeal competence, and near normal maxillary growth. There are various factors that may contribute in the prevention of palatal fistula includes adequate mobilization and tension free closure especially in wide clefts (wider the cleft, higher the fistula rate), good three layer closure irrespective of the technique 
used, proper realignment of the muscle of the soft palate in the mid line, and postoperative management.

The development of a fistula is one of the well-known complications that might develop after a surgical repair [3]. The incidence of fistula reported in a systematic review in cleft lip and palate cases was higher (17.9\%) than cases of cleft palate alone (5.4\%) with an over-all incidence of $8.6 \%$. The development of fistula might occur due to a number of factors such as age at operation, type and extent of clefting in addition to the surgical technique used [3] [4]. This research aims at studying the various factors that are associated with development of cleft palate. Gender difference appears to be one of the reported factors in literature. Males had a greater incidence of cleft lip and/or palate [5]-[11]. In contrast, females had more severe cases [5] [7]. On the other hand, a study done in Netherlands found no significant association between fistula development and age, gender or cleft type [12]. The effect of the surgical repair on maxillary growth is still controversial. However there are some factors that affect the maxillary growth for example the interventions done before surgery, cleft repair timing, technique of the surgery and post-operative protocol [13]. It has been reported that Veau-Wardill-Kliner technique of palatal repair shows a good mid-facial result in the long term [14]. The study aims at deciding the best surgical technique that is associated with the lowest rate of fistula. Furlow palatoplasty and two-flap palatoplasty are some of the surgical techniques described in the literature to be associated with low fistula rate (5.5\%) [15].

\section{Methods: Ease of Use}

\section{Selecting a Template}

\section{Methods}

Patients with cleft lip and/or palate operated at Khoula Hospital between the period of January, 2008 and July, 2015 were included in the study. Patients with cleft lip only were excluded from the study.

Veau classification was used to classify cleft palate cases (Table 1).

Fistula cases were diagnosed upon follow-up clinically on examination or based on history of nasal regurgitation when drinking. Our fistula cases included very anterior fistulas which are close to alveolar clefts since we depend on the patients' record files. There was no distinction and no clear differentiation made in the exam note between alveolar clefts and fistula.

Patient's data was extracted from the hospital "Al Shifa 2" system (Khoula

Table 1. Veau classification.

\begin{tabular}{cc}
\hline Veau classification & Description \\
\hline Veau I & Defects of the soft palate only \\
Veau II & Defects involving the hard and soft palate \\
Veau III & Defects involving the soft palate to the alveolus usually involving the lip \\
Veau IV & Complete Bilateral Clefts \\
\hline
\end{tabular}


Hospital). The data was analyzed using the "Statistical Package for Social Sciences" (SPSS) version 19 for Windows.

Cases were reviewed twice independently by the first two authors to extract fistula cases.

\section{Results}

Total of 362 cases were included in the study 182 (50.3\%) male and 180 (49.7\%) female patients. Mean age of those patients at time of surgery was 28.27 months (range 2.0 - 432.0 months old; Standard Deviation (SD) 53.74 months). Table 2 shows the age distribution according to gender.

Distribution of cleft palate cases was as follows: 88 cases (24.3\%) were Veau I, 156 (43.1\%) of cases were Veau II, 83 (22.9\%) cases Veau III and 35 (9.7\%) of cases were Veau IV (Figure 1).

Veau-Wardill-Kliner technique was used to repair 270 (74.6\%) of the cases. In 84 (23.2\%) cases, Von Langenback technique was used. While Bardach Salyer technique was used in only $5(1.4 \%)$ cases and Furlow repair in $3(0.8 \%)$ cleft palate cases. Table 3 shows the different techniques used for different types of clefts.

Palatal fistula has developed in 118 (32.6\%) of operated cases noting that 40 (11\%) of cases has failed to follow up. Mean time frame between surgery and fistula appearance was 8.77 months with a range of 1 to 78 months post-operation and SD of 13.51 months. Table 4 shows the distribution of fistula cases according to the type of surgical repair.

Chi square was used to investigate any relation between surgical technique used and appearance of fistula. It showed a p-value of $0.77 \%$, which meant that there was no significant association between surgical technique used and appearance of fistula.

Of the cases that developed fistula, 59.3\% (70 out of 118 cases) were males. The increase in male cases was statistically significant with a p-value of $0.041 \%$. Odds ratio for male to female risk of developing a fistula was 1.641 (Table 5).

\section{Extent of clefting usinng Veau Classification}

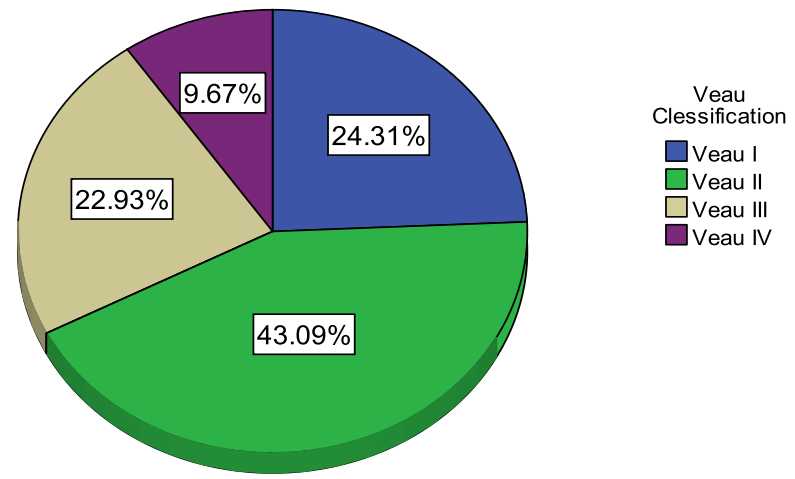

Figure 1. Extend of Clefting using Veau Classification of patients included in this study. 
Table 2. Mean ages and Cleft type distribution according to Gender.

\begin{tabular}{|c|c|c|c|c|}
\hline & & \multicolumn{2}{|c|}{ Gender } & \multirow{2}{*}{ Total } \\
\hline & & Male & Female & \\
\hline \multicolumn{2}{|c|}{ Mean Age at time of surgical repair (months) } & 26.962 & 29.583 & 28.265 \\
\hline \multicolumn{2}{|c|}{ Standard deviation of the age at time of surgery } & 54.8440 & 52.7121 & 53.7360 \\
\hline \multirow{5}{*}{$\begin{array}{l}\text { Extent of clefting } \\
\text { (Veau Clessification) }\end{array}$} & Defects of the soft palate only & 35 & 53 & 88 \\
\hline & Defects involving the hard and soft palate & 81 & 75 & 156 \\
\hline & $\begin{array}{l}\text { Defects involving the soft palate to the } \\
\text { alveolus usually involving the lip }\end{array}$ & 49 & 34 & 83 \\
\hline & Complete Bilateral Clefts & 17 & 18 & 35 \\
\hline & Total & 182 & 180 & 362 \\
\hline
\end{tabular}

Table 3. Surgical technique used in different types of cleft palate.

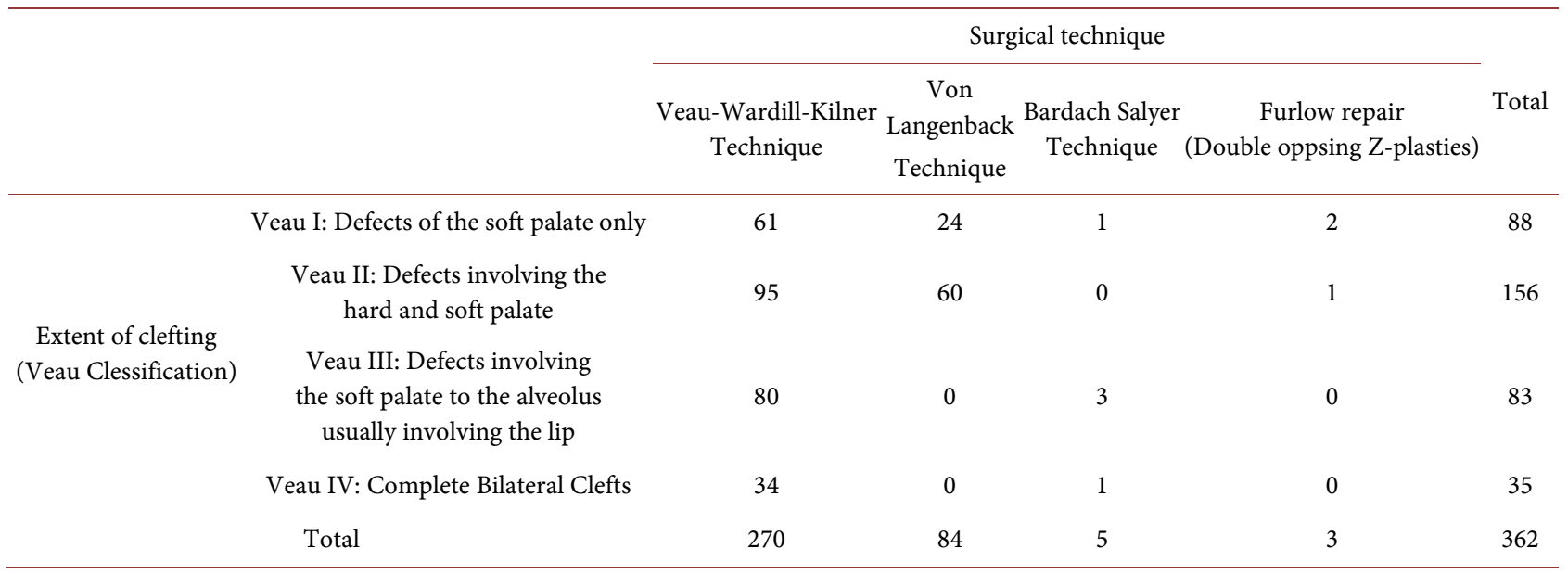

Table 4. Fistula Development distribution in relation to sex.

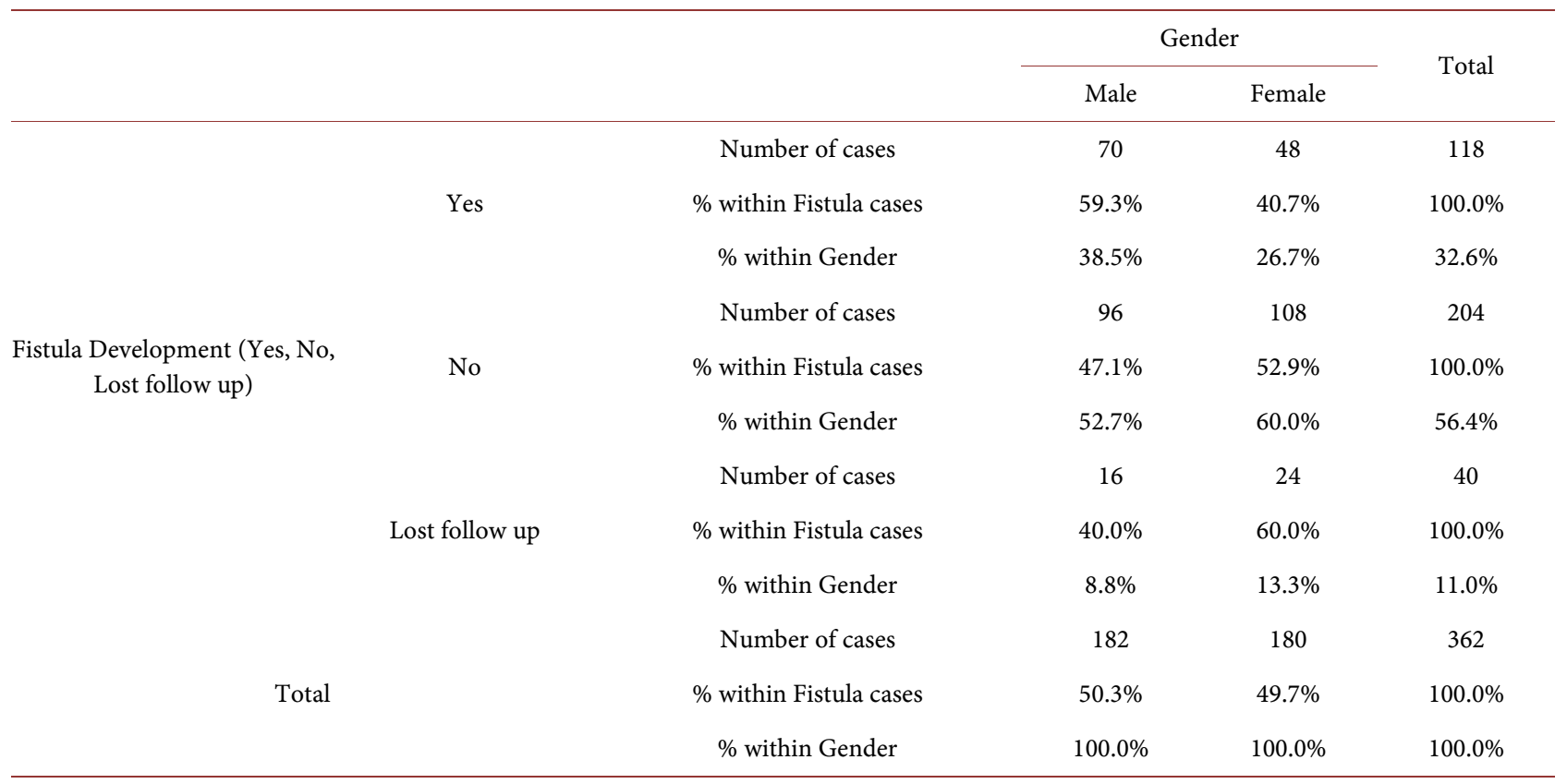


Table 5. Distribution of fistula according to type of surgical repair.

\begin{tabular}{|c|c|c|c|c|c|}
\hline & \multicolumn{3}{|c|}{ Fistula Development } & \multirow{2}{*}{ Total } \\
\hline & & Yes & No & Lost follow up & \\
\hline \multirow{10}{*}{ Surgical technique } & Veau-Wardill-Kilner & 88 & 142 & 28 & 258 \\
\hline & Technique & $34.1 \%$ & $55.0 \%$ & $10.9 \%$ & $100.0 \%$ \\
\hline & Vo I I & 28 & 57 & 11 & 96 \\
\hline & Von Langenback 1 echnique & $29.2 \%$ & $59.4 \%$ & $11.5 \%$ & $100.0 \%$ \\
\hline & \multirow{2}{*}{ Bardach Salyer Technique } & 1 & 3 & 1 & 5 \\
\hline & & $20.0 \%$ & $60.0 \%$ & $20.0 \%$ & $100.0 \%$ \\
\hline & Furlow repair & 1 & 2 & 0 & 3 \\
\hline & (Double opposing Z-plasties) & $33.3 \%$ & $66.7 \%$ & $.0 \%$ & $100.0 \%$ \\
\hline & \multirow{2}{*}{ Total } & 118 & 204 & 40 & 362 \\
\hline & & $32.6 \%$ & $56.4 \%$ & $11.0 \%$ & $100.0 \%$ \\
\hline
\end{tabular}

Correction of palatal fistula was planned in 43 (35.6\%) of fistula cases. Repair using local flaps was done in 24 (20.3\%) of total fistula cases. Veau-WardillKliner technique was used to repair 4 (3.4\%) fistula cases. Only one case $(0.8 \%)$ repaired primarily. While 2 fistula cases $(1.7 \%)$ has failed to follow up, no repair was done in 87 (73.7\%) of fistula cases within the study period and were advised to continue follow up (Table 6). Table 7 shows the surgical techniques used to repair the fistulae.

\section{Discussion}

The main goals of the surgical repair are to restore the normal anatomic alignment evidenced by no nasal regurgitation during food intake and to achieve a good functional outcome evidenced by good speech production.

Many centers have reported their cleft palate surgery outcomes in the literature. The cases of distribution between males and females was equal [3]. Other studies showed more cleft palate cases among males [5]-[11]. Higher incidence of isolated cleft palate cases was observed in females [11] [16]. Higher Prevalence of cleft lip and palate cases was noted than cases of cleft palate or lip only [17] [18].

Our study demonstrated a mean age of patients at time of operation of 28.27 months of age with a wide SD. Our current practice at Khoula hospital is age of approximately 12 months at time of operation. The obtained result can be due to late presentation of some cases.

Distribution of cases favored Veau II, followed by Veau I, Veau III and Veau IV.

Our study demonstrated that there was no significant association between surgical technique used and appearance of fistula. The distribution of cases on different surgical repair types might have an effect on the result. Veau-WardillKliner technique is the most commonly used technique at our institution. This might be a possible limitation of our study that is attributed to the nature of the study as it is a retrospective study. 
Table 6. Surgical repair of cases of fistula

\begin{tabular}{cccccc}
\hline & & \multicolumn{3}{c}{ Fistula developed } & \multirow{2}{*}{ Total } \\
\cline { 3 - 4 } & Yes & No fistula & Lost follow up & \\
\hline $\begin{array}{c}\text { Yes, operation planned } \\
\text { and/or done }\end{array}$ & 42 & 1 & 0 & 43 \\
Fistula Surgical repair & No, operation not planned & 74 & 203 & 2 & 279 \\
Lost follow up & 2 & 0 & 38 & 40 \\
Total & 118 & 204 & 40 & 362 \\
\hline
\end{tabular}

Table 7. Surgical technique used in cases of fistula

\begin{tabular}{|c|c|c|c|c|c|}
\hline & \multicolumn{3}{|c|}{ Fistula Developed } & \multirow{2}{*}{ Total } \\
\hline & & Yes & No fistula & Lost follow up & \\
\hline & \multirow{2}{*}{ Local Flap } & 24 & 0 & 0 & 24 \\
\hline & & $20.3 \%$ & $0.0 \%$ & $0.0 \%$ & $6.6 \%$ \\
\hline & \multirow{2}{*}{ No repair done } & 87 & 204 & 4 & 295 \\
\hline & & $73.7 \%$ & $100.0 \%$ & $10.0 \%$ & $81.5 \%$ \\
\hline \multirow{8}{*}{$\begin{array}{l}\text { Surgical technique of } \\
\text { fistula correction }\end{array}$} & \multirow{2}{*}{ Lost Follow up } & 2 & 0 & 36 & 38 \\
\hline & & $1.7 \%$ & $0.0 \%$ & $90.0 \%$ & $10.5 \%$ \\
\hline & \multirow{2}{*}{ Primary repair } & 1 & 0 & 0 & 1 \\
\hline & & $0.8 \%$ & $0.0 \%$ & $0.0 \%$ & $0.3 \%$ \\
\hline & \multirow{2}{*}{$\begin{array}{c}\text { Veau-Wardill-Kliner } \\
\text { Technique }\end{array}$} & 4 & 0 & 0 & 4 \\
\hline & & $3.4 \%$ & $0.0 \%$ & $0.0 \%$ & $1.1 \%$ \\
\hline & \multirow{2}{*}{ tal } & 118 & 204 & 40 & 362 \\
\hline & & $100.0 \%$ & $100.0 \%$ & $100.0 \%$ & $100.0 \%$ \\
\hline
\end{tabular}

In comparison with a study that compared association of fistula with rotation palatoplasty and conventional palatoplasty a statistically significant difference between the two groups. The conventional palatoplasty group included Furlow palatoplasty and Veau Wardill Kliner techniques. Overall fistula appearance was $17.7 \%$, in which $6 \%(4 / 67)$ was in the rotation palatoplasty group and $18 \%$ $(18 / 100)$ was in the conventional palatoplasty group [19].

A study done in university of Texas Southwestern Medical center compared patients with and patients without palatal fistula. They reported no significant difference between the two groups in regard to gender, age at palatoplasty and type of palate repair [20].

Palatal fistula rate excluding international unrepaired anterior palatal fistula at the alveolus in a retrospective study of cases repaired by one surgeon using Von Langenback Technique was 8 patients out of 177. Surgical repair was required in 2 cases out of those fistulae.

Higher incidence of fistulae was demonstrated in cases of bilateral cleft lip and palate [3]. A study done in New Zealand reported fistula rate of $12.8 \%$ (27 out of 211 children) [3]. Another study done in Canada at University of Toronto and University of Alberta showed a fistula rate of $0 \%$ (out of 148 and 34 operated 
cases respectively). They used Modified Von Langenbeck technique in their study [21]. A study compared one-flap with two-flap palatoplasty showed no statistical significance in terms of fistula development [22]. A study which focused on studying delayed cleft palate repair after 18 months in adopted patients showed $33 \%$ incidence of velopharyngeal insufficiency compared with $13 \%$ in the group repaired between 6 to 12 months of age [1].

Our study demonstrated a high rate of fistula development. There was no significant association between surgical technique used and development of fistula. However, there was significant increase in cases of fistula in males.

A meta-analysis done by Bykowski and others showed a significant association between Veau classification and fistula development. Fistula cases were more among Veau IV cases [23]. Another study showed the same association between fistula development and Veau class IV in a retrospective study of cases done by one surgeon [24].

At Khoula hospital we follow a strict post-op cleft palate feeding protocol. The protocol states liquid diet feeding for 5 days followed by 2 weeks of soft diet.

A contributing factor to the failure of cases to follow up is the fact that Khoula hospital is a tertiary plastic center that deals with cases from all across the country. Problems of transport and the distance between area of residence and our hospital might limit the ability of patients to continue to follow up. Another factor is that appointments are around 6 months to a year apart. Some parents might simply forget about the appointment. Some parents might be satisfied with their results and will stop following up.

Knowing the factors associated with palatal fistula post-operatively will help us reduce its incidence or even prevent it. Hence reduce the number of operations need to repair the fistula, decrease follow-up appointments and improve overall patient's satisfaction.

After the text edit has been completed, the paper is ready for the template. Duplicate the template file by using the Save As command, and use the naming convention prescribed by your journal for the name of your paper. In this newly created file, highlight all of the contents and import your prepared text file. You are now ready to style your paper.

\section{Limitations}

Our study faced a number of limitations beginning with the fact that the palate repair was done my multiple surgeons with different techniques and different level of experience. Since it is a retrospective study, we depended on the documentation and records of patient's files. The extraction of data was difficult in some cases as the exams findings and detection of fistulae differs with different surgeons especially if the fistula is very small and does not pose any clinical symptoms. Our study had an overestimated number of fistulae due to the fact that we included anterior palatal fistulae in continuity with alveolar clefts. The reason for that is that our exam notes did not clearly distinct between alveolar clefts and fistulae. Some of the most anterior fistulae which are in continuity 
with alveolar cleft can be corrected at the time of alveolar bone grafting. We did not study the palatal width as it was not measured and could not be traced from the records although it was found as non contributing factor to fistula appearance in some studies [24]. The site of fistula formation was not included in our study as it was not mentioned in most of the patient's records.

\section{Conclusion}

Closure of fistula located at any part of human body is a surgical challenge so as Palatal fistula. No such study was conducted in Oman to show the incidence of Palatal fistula after primary palate repair. The aim of this study was not only to know the incidence but also the contributing factors which leads to this complication which is very difficult to treat. By knowing and evaluating the factors associated with development of palatal fistula, help us to standardize the surgical techniques to prevent/reduce the incidence of fistula formation. This helps to improve the overall results by avoiding the need for another anaesthesia, hospital stay, number of operations need to repair the fistula, decrease follow-up appointments and improve overall patient's satisfaction. By keeping this retrospective study as a baseline we can proceed with prospective studies after making the appropriate strategies and protocols for the repair of cleft palate to obtain better results.

\section{References}

[1] Follmar, K.E., Yuan, N., Pendleton, C.S., Dorafshar, A.H., Kolk, C.V. and Redett R.J. (2015) Velopharyngeal Insufficiency Rates after Delayed Cleft Palate Repair: Lessons Learned from Internationally Adopted Patients. Annals of Plastic Surgery; 75, 302-305. https://doi.org/10.1097/SAP.0000000000000082

[2] Adeyemo, W.L., Adeyemi, M.O., Ogunsola, F.T., Ogunlewe, M.O., Ladeinde, A.L.», Mofikoya, B.O. and Butali, A. (2013) Prevalence and Bacteriology of Bacteremia Associated with Cleft Lip and Palate Surgery. The Journal of Craniofacial Surgery, 24 , 1126-1131. https://doi.org/10.1097/SCS.0b013e31828016e8

[3] Hardwicke, J.T., Landini, G. and Richard, B.M. (2014) Fistula Incidence after Primary Cleft Palate Repair: A Systematic Review of the Literature. Plastic and Reconstructive Surgery, 134, 618e-627e. https://doi.org/10.1097/PRS.0000000000000548

[4] Phua, Y.S. and De Chalain, T. (2008) Incidence of Oronasal Fistulae and Velopharyngeal Insufficiency After Cleft Palate Repair. An Audit of 211 Children Born Between 1990 and 2004. Cleft Palate-Craniofacial Journal, Vol. 45, No. 2, 172-8. https://doi.org/10.1597/06-205.1

[5] Nagase, Y., Natsume, N., Kato, T. and Hayakawa, T. (2010) Epidemiological Analysis of Cleft Lip and/or Palate by Cleft Pattern. Journal of Maxillofacial and Oral Surgery, 9, 389-395. https://doi.org/10.1007/s12663-010-0132-6

[6] González, B.S., López, M.L., Rico, M.A. and Garduno, F. (2008) Oral Clefts: A Retrospective Study of the Prevalence and Predisposal Factors in the State of Mexico. Journal of Oral Science, 50, 123-129. https://doi.org/10.2334/josnusd.50.123

[7] Manyama, M., Rolian, C., Gilyoma, J., Magori, C.C., et al. (2011) An Assessment of Orofacial Clefts in Tanzania. BMC Oral Health, 11, 5.

https://doi.org/10.1186/1472-6831-11-5 
[8] Silberstein, E., Silberstein, T., Elhanan, E., Bar-Droma, E., et al. (2012) Epidemiology of Cleft Lip and Palate among Jews and Bedouins in the Negev. IMAJ, 14, 378381.

[9] Kesande, T., Muwazi, L.M., Bataringaya, A. and Rwenyonyi, C.M. (2014) Prevalence, Pattern and Perceptions of Cleft Lip and Cleft Palate among Children Born in Two Hospitals in Kisoro District, Uganda. BMC Oral Health, 14, 104. https://doi.org/10.1186/1472-6831-14-104

[10] Kianifar, H., Hasanzadeh, N., Jahanbin, A., Ezzati, A. and Kianifar, H. (2015) Cleft lip and Palate: A 30-Year Epidemiologic Study in North-East of Iran. Iranian Journal of Otorhinolaryngology, 27, 35-41.

[11] Sabbagh, H.J., Mossey, P.A. and Innes, N.P.T. (2012) Prevalence of Orofacial Clefts in Saudi Arabia and Neighboring Countries: A Systematic Review. The Saudi Dental Journal, 24, 3-10. https://doi.org/10.1016/j.sdentj.2011.11.001

[12] Landheer, J.A., Breugem, C.C. and Mink van der Molen, A.B. (2010) Fistula Incidence and Predictors of Fistula Occurrence after Cleft Palate Repair: Two-Stage Closure Versus One-Stage Closure. Cleft Palate-Craniofacial Journal, 47, 623-630. https://doi.org/10.1597/09-069

[13] Shi, B. and Losee, J.E. (2015) The Impact of Cleft Lip and Palate Repair on Maxillofacial Growth. International Journal of Oral Science, 7, 14-17. https://doi.org/10.1038/ijos.2014.59

[14] Choudhary, S., Cadier, M.A., Shinn, D.L., Shekhar, K. and McDowall, R.A. (2003) Effect of Veau-Wardill-Kilner Type of Cleft Palate Repair on Long-Term Midfacial Growth. Plastic and Reconstructive Surgery, 111, 576-582. https://doi.org/10.1097/01.PRS.0000041945.51785.58

[15] Winters, R., Carter, J.M., Givens, V. and St. Hilaire, H. (2014) Persistent Oro-Nasal Fistula after Primary Cleft Palate Repair: Minimizing the Rate via a Standardized Protocol. International Journal of Pediatric Otolaryngology, 78, 132-134. https://doi.org/10.1016/j.ijporl.2013.11.007

[16] Harville, E.W., Wilcox, A.J., Lie, R.T., AByholm, F. and Vindenes, H. (2007) Epidemiology of Cleft Palate Alone and Cleft Palate with Accompanying Defects. European Journl of Epidemiology, 22, 389-395. https://doi.org/10.1007/s10654-007-9129-y

[17] Lee, C.W., Hwang, S.M., Lee, Y.S., Kim, M. and Seo, K. (2015) Prevalence of Orofacial Clefts in Korean Live Births. Obstetrics and Gynecology Science, 58, 196-202. https://doi.org/10.5468/ogs.2015.58.3.196

[18] Mirfazeli, A., Kaviany, N., Hosseinpour, K.R. and Golalipour, M.J. (2012) Incidence of Cleft Lip and Palate in Gorgan-Northern Iran: An Epidemiological Study. Oman Medical Journal, 27, 461-464. https://doi.org/10.5001/omj.2012.110

[19] Kahraman, A., Yuce, S., Kocak, O.F., Canbaz, Y., Guner, S.I., Atik, B. and Isik, D. (2014) Comparison of the Fistula Risk Associated with Rotation Palatoplasty and Conventional Palatoplasty for Cleft Palate Repair. The Journal of Craniofacial Surgery, 25, 1728-1733. https://doi.org/10.1097/SCS.0000000000000967

[20] Muzaffar, A.R., Byrd, H.S., Rohrich, R.J., Johns, D.F., et al. (2001) Incidence of Cleft Palate Fistula: An Institutional Experience with Two-Stage Palatal Repair. Plastic and Reconstructive Surgery, 108, 1515-1518. https://doi.org/10.1097/00006534-200111000-00011

[21] Stewart, T.L., Fisher, D.M., Olson, J.L. and Von Langenbeck, M. (2009) Cleft Palate Repair Using an Anterior Triangular Flap: Decreased Incidence of Anterior Oronasal Fistulas. Cleft Palate-Craniofacial Journal, 46, 299-304.

https://doi.org/10.1597/07-185.1 
[22] Rossell-Perry, P., Cotrinal-Rabanal, O. and Caceres-Nano, E. (2015) One-Flap Palatoplasty: A Cohort Study to Evaluate a Technique for Unilateral Cleft Palate Repair. Plastic and Reconstructive Surgery Global Open, 3, e373. https://doi.org/10.1097/GOX.0000000000000342

[23] Bykowski, M.R., Naran, S., Winger, D.G. and Losee, J.E. (2015) The Rate of Oronasal Fistula Following Primary Cleft Palate Surgery: A Meta-Analysis. Cleft Palate and Craniofacial Journal, 52, e81-7. https://doi.org/10.1597/14-127

[24] Yuan, N., Dorafshar, A.H., Follmar, K.E., Pendleton, C., Ferguson, K. and Redett, R.J. (2015) Effects of Cleft Width and Veau Type on Incidence of Palatal Fistula and Velopharyngeal Insufficiency After Cleft Palate Repair. Annals of Plastic Surgery.

Scientific Research Publishing

Submit or recommend next manuscript to SCIRP and we will provide best service for you:

Accepting pre-submission inquiries through Email, Facebook, LinkedIn, Twitter, etc. A wide selection of journals (inclusive of 9 subjects, more than 200 journals)

Providing 24-hour high-quality service

User-friendly online submission system

Fair and swift peer-review system

Efficient typesetting and proofreading procedure

Display of the result of downloads and visits, as well as the number of cited articles

Maximum dissemination of your research work

Submit your manuscript at: http://papersubmission.scirp.org/

Or contact mps@scirp.org 